Chapman University

Chapman University Digital Commons

Education Faculty Articles and Research

Attallah College of Educational Studies

$12-15-2017$

\title{
"In A Position I See Myself in:" (Re)Positioning Identities and Culturally-Responsive Pedagogies
}

Noah Asher Golden

Follow this and additional works at: https://digitalcommons.chapman.edu/education_articles

Part of the Bilingual, Multilingual, and Multicultural Education Commons, Curriculum and Social Inquiry Commons, Educational Assessment, Evaluation, and Research Commons, Educational Leadership Commons, Educational Sociology Commons, Elementary and Middle and $\underline{\text { Secondary Education Administration Commons, Other Education Commons, Race and Ethnicity }}$ Commons, and the Social and Philosophical Foundations of Education Commons 


\section{"In A Position I See Myself in:" (Re)Positioning Identities and Culturally- Responsive Pedagogies}

\section{Comments}

This is an Accepted Manuscript of an article published in Equity \& Excellence in Education, volume 50, issue 4, in 2017, available online at DOI: 10.1080/10665684.2017.1393641. It may differ slightly from the final version of record.

\section{Copyright}

University of Massachusetts Amherst College of Education 
Running head: (RE)POSITIONING IDENTITIES

"In a position I see myself in:" (Re)positioning identities and culturally-responsive pedagogies

Noah Asher Golden, Ph.D.

Attallah College of Educational Studies

Chapman University

Orange, CA 92866 USA

ngolden@chapman.edu 


\begin{abstract}
Culturally-responsive pedagogies require moving beyond blanket assumptions about learners to focus deeply on local meaning-makings. This narrative analysis case study examines the ways a twenty-year-old African American man challenges the negative educational identity with which he is forced to contend as he navigates a large and complex urban public school system. The ways in which Jamahl, a seeker of a High School Equivalency, refuses interpellation as an uneducated learner destined to be "nothin" "provides insight as to how formal education might be more responsive to learners' negotiation of deficiency discourses. Embracing agency, specifically through awareness of the ways Jamahl employs (re)positioning practices, this narrative analysis case study highlights paths for researchers and practitioners to tap into learners' resources to recognize and foster powerful learning identities.
\end{abstract}

Keywords: agency, adolescent literacy, African American male students, narrative analysis 
You actually did something with your life, and you actually became something...that's how I looked at it... in a position that I see myself in. -Jamahl, referencing himself

\section{Introduction}

During an early morning meeting, teachers at The Opportunity Center are discussing adolescent students who are "off-track" or a cause for concern. One of the five teachers present brings up a student named Jamahl ${ }^{1}$, saying that he has low reading and writing skills. The teacher asserts that Jamahl hides his low literacy skills in class, leading to a chorus of agreement and nods from around the table.

Jamahl is African American and attends an educational program where the overwhelming majority of his peers are also of color and minoritized ${ }^{2}$. Like many of his peers, he hails from an urban neighborhood community experiencing economic poverty and long-term lack of investment. He is seeking expanded life opportunities through education in a society that routinely dehumanizes African American men.

As a researcher and former literacy coach at The Opportunity Center, I am concerned with the sort of support and interventions used to create authentic learning opportunities in literacy education for the young people aged 17-21 at this and similar "second-chance" secondary-level programs. This research intends to move beyond deficit framings of Jamahl, ones that posit a lack of literacy skills while seeing little in the way of strengths upon which to build. This needed shift goes far beyond individual teacher practice at one educational program; working for educational equity and opportunity requires deeper understandings of learners' experiences and funds of knowledge. Indeed,

\footnotetext{
${ }^{1}$ All names, including the names of educational institutions and programs, are pseudonyms.

2 I say 'minoritized' as opposed to 'minorities' to call attention to the social processes that privilege some people at the expense of others. In other words, no one is born a 'minority;' social arrangements position and produce majority and minority communities. 'Minoritized' describes people marginalized due to their linguistic or cultural practice, ethnic or racial affiliation, gender, or class, among other aspects of identity.
} 
deficit framings are systemic: within the metrics utilized at literacy education sites like The Opportunity Center, Jamahl is viewed only in terms of his deficiencies on the practice exams that serve as stages towards the High School Equivalency. Moving towards justice in and through schooling means finding ways to know learners like Jamahl in ways that foreground their desires, cultural practices, and individual strengths.

This narrative analysis case study engages Jamahl's identity negotiations as he navigates the New York City Department of Education, the nation's largest urban public school system, in efforts to earn a secondary credential. The questions that guide this work are "How does Jamahl understand the ways he is positioned in educational disparity discourse?” and, perhaps more importantly, "How does Jamahl (re)negotiate and resist these positionings?" Jamahl took part in a larger study investigating the individual strategies and cultural resources used by young men of color navigating their deficitoriented educational program. In this article, I analyze Jamahl's narratives about his educational history and offer an interpretation grounded in systematic narrative analysis (Bamberg, 2004a; Daiute, 2014; Gee, 1991, 2011; Riessman, 1993, 2008). This analysis, I argue, speaks to the ways that research and public pedagogies can engage learners' resources through dialogical and responsive practice.

\section{Literature Review}

The "culture of poverty" (Harrington, 1962) paradigm that suggests poor people share an entrenched set of values, and that these values are the cause of undesirable educational and other outcomes, remains prevalent in popular discourses on race and class. This paradigm pathologizes minoritized people, in effect blaming them for opportunity gaps and structural racism (Gorski, 2012). Resisting the stubborn staying 
power of this paradigm, educational research has offered a growing body of culturallyrelevant and culturally-responsive pedagogies (e.g., Ball \& Trainor, 2016; LadsonBillings, 1995; Milner, 2011; Sealey-Ruiz, 2011; Sleeter, 2012). Culturally-responsive pedagogies have challenged deficit models (e.g., Borrero, Flores, \& de la Cruz; 2016; Carrillo, 2016; Ladson-Billings, 2006), demonstrating the cultural assumptions and practices in the formal education process that privilege some children at the expense of others. Recent work (e.g., Irizarry, 2017; Paris \& Alim, 2014, 2017; Paris, 2012; Rosa \& Flores, 2017; San Pedro, 2017) regarding culture and the education of minoritized youth has argued that this work must be culturally sustaining as opposed to transitional and assimilating, and that culture must not be reified in ways that preclude community-based practices (i.e., evolving practices that may not be associated with past-oriented traditional or heritage-based ways of being). This scholarship explores how a multiplicity of identities and practices can be understood as cultural processes, thus resisting static and reductive notions of culture. Rather than understanding cultural relevance or responsiveness solely as the inclusion of a particular text or celebration, current scholarship on culturally-responsive pedagogy deepens the understanding that minoritized youth have much to teach us and are not simply "underachieving" people constituting objects of research (Ladson-Billings, 2014).

It remains critically important for researchers and educators to build knowledge in order to be responsive to the challenges people face as they agentively negotiate issues of identity that include positionings based on ability status, location, race, ethnicity, age, gender, and sexual orientation. This work resists simplistic narratives of success that locate deficits within people rather than discursive positioning and social systems 
(Golden, 2015). Dominant discourses on African American people include notions of tragedy, failure, and violence (Kirkland, 2013; Noguera, 2009, Winn; 2012), and there is great need for research situated within the experience and understandings of African American boys and young men to counter these gendered cultural myths (Payne \& Brown, 2010). Grounding research and responsive pedagogies in minoritized people’s experiences and understandings is one means of focusing on people's desires and resisting portrayals of marginalized people as solely "at-risk," damaged, or conquered (Tuck, 2009).

\section{Theoretical Framing}

Drawing on two bodies of research, counter-storytelling as a form of double consciousness and identity formation through positioning, this narrative analysis case study documents the ways that Jamahl navigates undesirable positionings of who he is and can become. Over the past decade and a half, we have built on the long history of counter-storytelling (e.g., Du Bois, 1903/2008, Solorzano \& Yosso, 2001) to learn much about the ways people negotiate identities and resist undesirable positioning practices (Solorzano \& Yosso, 2010; Rosario-Ramos \& Johnson, 2014). Recent work (e.g., Allen, 2017; Butler, 2017) has focused on the resources and cultural tools people draw upon as they work to negotiate and resist disparaging discourses.

\section{Double consciousness and counter-storytelling}

In the (1903/2008) seminal work The souls of Black folk, Du Bois opens with the question that lingers between him and 'the other world' of White America: "how does it feel to be a problem?" Engaging race and America, Du Bois introduces the concept of double-consciousness, which can be understood as an internalized oppression, an 
embodiment of racism, or the color line alive in people's bodies. Du Bois elaborates:

It is a peculiar sensation, this double-consciousness, this sense of always looking at one's self through the eyes of others, of measuring one's soul by the tape of a world that looks on in amused contempt and pity. One ever feels his two-ness - an American, a Negro; two souls, two thoughts, two unreconciled strivings; two warring ideals in one dark body, whose dogged strength alone keeps it from being torn asunder. (p.1)

The pejorative framings of Black people and other people of color referenced by Du Bois very much persist, and are grounded in the origins of our society, a product of institutionalized racism and its structural legacies of slavery (Delgado \& Stefancic, 2012). Du Bois' concept of double consciousness has informed much research and conceptual work on how social structures and discourses interact, position, take root, solidify, and are enacted and resisted. Double consciousness entails looking at oneself through the eyes of another while still having "unreconciled strivings" that place the two self-conceptions in conflict.

One way in which people resist proffered positions they find undesirable is to engage in counter-storytelling, the practice of voicing experiences not widely heard in ways that can challenge privilege, inequities, and inequalities (Solorzano \& Yosso, 2001, 2010). Recent research has focused on ways that engaging specific endeavors (e.g., college reentry for Black mothers) can serve as a means to resist entrenched stereotypes and define oneself (Sealey-Ruiz, 2013), or ways that a community-based institution can challenge inequitable conditions through critical literacy frameworks (Rosario-Ramos \& Johnson, 2014). The resources that people draw upon can be as varied as "unofficial" knowledge about ability (e.g., Connor, 2007), personal experience in navigating complex social spaces (e.g., Fernandez, 2016), reflections on power imbalances (e.g., Cho, 2016), or even silence as a means of resistance (e.g., San Pedro, 2015). Documenting the use of 
these resources in counter-storytelling is not necessarily an offering of a "truer" version of reality in a positivist sense, but a more honest one situated within people's lived realities (Atwood \& Lopez, 2014).

\section{Identity formation and positioning}

People's identities, understood here to include the ways in which people are recognized as particular kinds of people by others, are shaped through social acknowledgements that are inextricably intertwined with participation in particular sets of practices, including literacies (Gee, 2001). Dominant discourses, institutionalized social processes, and systems position and marginalize some learners (Bourdieu, 1977; Davies and Harré, 1990; Holland \& Leander, 2004). These pathologizing framings have the potential to distort identities and senses of self, limiting access and participation in practices deemed desirable. People can and do resist by exercising their agency, understood here as "the strategic making and remaking of selves, identities, activities, relationships, cultural tools and resources, and histories, as embedded within relations of power" (Moje \& Lewis, 2007, p.18). This agentive negotiation is thus a challenge to the ways they have been positioned. People are interpellated, or hailed into particular kinds of subject positions, through the invoking of dominant discourses in social interactions. Positioning theory maintains that not all people have equal access to the rights and duties to enact particular kids of meaningful actions in specific contexts, and that all people are positioned in or through speech acts and other discourse (Harré and van Langenhove, 1999; Harré, Moghaddam, Cairnie, Rothbart, \& Sabat, 2009). Multiple studies (e.g., Erstad, Sefton-Green, \& Vasbø, 2009; Fairbanks \& Arial, 2006; Hall, 2012) have documented the ways that both proffered and self-directed positionings can increase or 
decrease the valuing of individuals in learning spaces over time. In the past decade and a half, there have been important contributions to the literature on the resources people use as they resist and remake identities by seeking out new positions. Such works conceptually frame particular resources as funds of knowledge (Moll, González, \& Amanti, 2005), community-based knowledge (Purcell-Gates, 2013), meditational means (Hull \& Zacher, 2007), or organic critical literacies (Campano, Ghiso, \& Sánchez, 2013). These resources can also include literacy practices such as playwriting (e.g., Winn, 2012), texts literally inked onto people's skin (i.e., tattoos, Kirkland, 2009), the use of classroom identity artifacts (e.g., Leander, 2002; Wortham, 2004), or multimodal means (e.g., Hull \& Katz, 2006). The use of these resources and tools are central to the agentive seeking of new positions.

\section{Research Methodology}

Recognizing and documenting agency poses both theoretical and methodological challenges. Research must move beyond conceptual framings that understand the individual solely as a constellation of deterministic socio-cultural forces while still acknowledging the power of these forces to define or distort identities. To address my questions, I employ narrative analysis, an approach well-suited to exploring and documenting negotiated identities (Riessman, 1993, 2008). Narrative analysis offers a means of acknowledging and documenting the tensions that are often present as people work to negotiate their identity through position-taking practices. Embracing this complexity, narrative analysis offers a means of exploring human agency and structural limitations (Maynes, Pierce, \& Laslett, 2008), as people position themselves in relation to positioning discourses (Bamberg, 2004a; Harré and van Langenhove, 1999; Harré et al., 
2009; Moje \& Lewis, 2007).

\section{Participant and data sources}

At the time of the study, Jamahl was a 20 year-old African American man seeking his High School Equivalency (HSE) credential at The Opportunity Center. The center, a HSE storefront program in Midtown Manhattan, is one educational site of a larger citywide program serving between 8,000 and 9,000 learners per year and run by New York City's Department of Education. The students in the program are aged 17 to 21 , and the overwhelming majority were and continue to be of color, poor or working class, and primarily male.

During his time as a learner in the program, Jamahl traveled over an hour each morning to The Opportunity Center via public transportation from the housing project where he lived with his grandparents and siblings. Jamahl was one of twelve young men who chose to participate in the wider study investigating the use of cultural tools by young men of color as they negotiated educational disparity discourse in their educational context. All young men at The Opportunity Center were invited to participate in the study, and Jamahl chose come to eleven focus groups and two follow-up individual interviews over the five months of data collection. Rapport with Jamahl and the other participants was developed through an after-school Men's Group dedicated to a Youth Participatory Action Research (YPAR) exploring the ways that secondary-level education might better connect with the lived realities and aspirations of young men of color from neighborhoods experiencing generations of underinvestment. This YPAR work was done through my role as the literacy coach at The Opportunity Center, and focused on classroom practice and dialogue with the young men's teachers. While the two projects 
intermingled in generative ways, this YPAR work was distinct from the study of the cultural tools the young men employed as they navigated deficiency discourse.

To generate discussion during the focus groups and interviews that yielded the data for this study, I shared selections from educational histories written by other young men in a previous Men's Group held at The Opportunity Center. I then asked Jamahl and the other participants questions about these stories, and followed with questions about whether the participants' own experiences were similar to or different from the selections we discussed. The data for this study are Jamahl's narratives, which were culled from these focus group discussions and individual interviews, and were chosen based on their relation to the research focus. The choice to do a narrative analysis case study of Jamahl's contributions stems from a desire as a researcher to highlight the fact that these young people are individuals, with individual experiences and understandings, as well as individual strategies employed to (re)position themselves when facing prevalent deficiency discourses.

\section{Analysis}

There remain considerable debates in the field of narrative analysis as to what constitutes a narrative (Chandler, Lalonde, \& Teucher, 2004, p.249; Riessman, 1993, p.17). Narrative is understood here as a bounded unit of speech that serves as a "recounting of things spatiotemporally distant," with those things being a "perceived sequence of non-randomly connected events" (Toolan, 1988, p.2). As situated actions, narratives offer meanings that the speaker intends for the audience, meanings that carry weight with regard to intentions and future action (Riessman, 2008) as well as efforts to renegotiate the ways in which the speaker is or has been positioned (Bamberg, 2004b). 
When recounted in the form of narrative, acceptance, refusal, or negotiation of a positioning practice reveals the narrator's identity, demonstrating the ways the speaker takes up or resists dominant discourses (Bamberg, 2004a). In this study, I searched for Jamahl's recounting of sequences of events and interpreted them as performed and situated actions that index his identity positions and desired positions. I requested feedback from Jamahl on emerging interpretations during the two individual interviews that took place during the data collection period, and also invited Jamahl to participate in an additional interview in which he reflected on the completed analysis. This member checking (Lincoln \& Guba, 1985) allowed Jamahl to inform and respond to the distinct layers of analysis detailed below. Despite this process, Jamahl's narratives and my analysis of them must be understood as situated in particular contexts, and, as such, partial as opposed to holistic or authentic (Mazzei \& Jackson, 2012). My positionality as a middle-class White man and literacy coach at Jamahl's HSE center undoubtedly influenced both what Jamahl chose to share as well as the intended interpretations of them. While recognizing these limitations, I worked to mitigate them through the systematic methods detailed below.

To explore Jamahl's agency, specifically his efforts to (re)position himself when faced with an undesirable or offensive subject position, I engaged three methodological steps: analysis of content (Riessman, 2008), analysis of narrative structure (Gee 1991, 2011; Riessman, 1993, 2008), and a significance analysis of a specific evaluative device (Daiute, 2014). Each layer of analysis offered deeper approaches to building meaning from the discourse (Riessman, 1993). The initial layer of analysis focused on the content of the narratives, primarily Jamahl's expressions of intense dissatisfaction regarding the 
ways he has been positioned within academic learning spaces. Similar themes were consistent across narratives collected from other participants in the larger study. To document Jamahl's individual strategies for negotiating these positionings, it was necessary to engage additional layers of analysis. Structural and significance analyses allowed me to extend the analysis to document individual identity negotiations. Structural analysis focused on the ways each narrative was organized, going beyond the content of the narrative to explore how the order and other features produce meanings that achieve the narrator's strategic aims. To facilitate structural analysis of Jamahl's narratives, the narratives were rendered into 'stanzas,' or idea units, to explore their form and meaning (Gee, 1991, 2011). Rendering Jamahl's narratives in this way allowed me to look at the order of different idea units within each narrative, a framework that takes into account each idea unit's location to and relation with the entire narrative. Analyzing these relationships and locations engendered new interpretations of Jamahl's narratives, particularly around his efforts at (re)positioning himself.

Finally, in engaging significance analysis, I explored how the narrator uses specific evaluative devices that indicate desired perceptions of the narrator as well as personal feelings about specific events (Daiute, 2014). During this layer of analysis, one particular evaluative device emerged as serving what Gee terms a "significance-building tool" (Gee, 2011, p.92). The foci on structure and use of this tool that emerged during the significance analysis are integral to understanding Jamahl's efforts at resisting disparaging discourses and (re)positioning himself in learning spaces.

By delving into what precedes and follows Jamahl's use of the recurring significance-building tool, the evaluative device 'actually', I built an argument on the 
meaning and function the term serves in the narratives. Also important in the significance analysis are deitics, words whose reference must be determined from the context. These, too, I argue, demonstrate agentive moves, particularly when a narrator imagines himself from the vantage point of another person, as Jamahl does in what follows.

To invite the reader into my analytical process, I rendered two of Jamahl's entire narratives into stanzas. In the shared narrative rendered for analysis, I gave each stanza, or idea unit, a title to represent what I see as its central theme, and words or phrases that were said with emphasis have been underlined. As the narratives are rendered below, "/" indicates a non-final intonation contour, "//" marks a final intonation contour, a comma indicates a pause, and "-“" represents a moment when the narrator breaks off to say something else (Gee, 2011, p.111). Jamahl's uses of the significance-building tool 'actually' have been bolded to highlight its use.

\section{Findings}

Jamahl's use of the word "actually" emerged as a significance-building tool in his narratives, and understanding his use of this evaluative device built knowledge on his identity enactments and negotiations. Jamahl agreed with this reading of his use of "actually" as a device important to his agentive (re)positionings during the member checking process. He shared that while he had not been aware of the ways this device operated in his narratives, he agreed that this significance-building tool informed his reflections on his experience as an important means for him to resist undesirable framings and seek out new positions.

\section{Seeking new positions through "actual" experience}


In a brief narrative shared explaining why he left his first high school, Jamahl said he was upset by the way he and other students in a class for "struggling learners" were surrounded by "negative energy." Jamahl related that he experienced negative remarks suggesting that he and his peers were incapable of learning. One such remark, directed at him by a teacher during his junior year, "triggered in [his] head, wow, I'm not even supposed to be in this class." His response was that he "just stopped going to school...'cause that was like the only way I could get out the school was to stop going and actually trying myself to get back into another school." This was one of the first times Jamahl used the word "actually" in our focus group discussions, and analysis demonstrated that it serves a powerful function in his narratives. Jamahl was aware that his decision to leave the school positioned him as a 'drop-out,' and that this was a negative framing of his identity. Because of this negative interpellation, Jamahl immediately worked to (re)position himself in and through the narrative, a move signaled by his use of the significance-building tool "actually". This connects with Du Bois' concept of double-consciousness: Jamahl was aware of the negative framing of who he was seen to be, and his narratives offer insight into his work to position himself the way he wished to be viewed. Aware that his leaving castigated him as a "drop-out", he immediately spoke to his "actual" experience: he was not leaving high school because he did not want to be in school; he actually — as opposed to what the dominant discourse about a young man of color who stops going to school might be- was trying to get into another educational program. The order of these meanings in the narrative highlights his work to declare that he was not who he had been positioned to be. 
"Actually" emerged as an evaluative device as it often occurs in Jamahl's narratives following the recounting of an event in which he was negatively positioned. Jamahl's narrative of how he eventually came to his High School Equivalency Center, which I have entitled "Jamahl's Story of Looking for New Schools," evidences his use of "actually", and shows how it functions in his identity negotiations. This narrative was shared in an early focus group, immediately following the above recounting of his decision to leave his first high school, and shows Jamahl resisting how he has been positioned. In this narrative, he told his audience (me and the other members of the focus group) of the processes he engaged to find other secondary-level educational programs.

\section{Table 1}

\section{Jamahl's Story of Looking for New Schools}

\section{Stanza 1: Looking for a School}

1.well when I was looking, um, I was looking on the internet//I was looking 2.in/what else was I looking?/ I was looking-I was looking on the internet/ I was 3.looking, um, since we have-we have like, uh-a [city name omitted] Housing 4.Authority newspaper like/and I would look in that// and they would actually bring 5.up lists of schools/different schools/different GED/and stuff like that//

\section{Stanza 2: I Actually Found Coolidge High School}

6.And/I found, um, I actually found one//I found Coolidge High School/that's

7. actually right across the street from the high school that I went to//

\section{Stanza 3: I did not Like Coolidge because I knew everyone there}

8. and I went there//and didn't like it/I didn't like it because of the fact that/because 9. of the fact that/I knew everyone there//and - (tapping fingers) I didn't-I knew 10.everyone there/and-I don't know//

\section{PI: From-from your neighborhood?}

\section{Stanza 4: I Knew a lot of Kids at Coolidge}

11.from my neighborhood/or just being-the fact that I go to the school and a lot of 12.kids that was from my old high school, they transferred over and went to that 13.school//so I knew, I knew, I knew a lot of kids therel/ 
14. and at the time/well/at the time I was/I was feeling it/but I wasn't feeling it at 15. the same timel/and like-what I mean by that like-I was feeling the mood to go to 16.school/but I just wasn't feeling the school and what was in the school/and it was 17. making me lose interest//

\section{Stanza 6: It wasn't something I was looking for}

18. and then after that/the teachers that was in there/they were like, um, there was 19.bookwork and stuff/I I could do it/but it just wasn't something that I was looking 20.for/seeking//

\section{Stanza 7: I Was Actually Doing Something: Working and Going to School}

21. So I stopped doing that/and I continued to- to work// so I wasn't in the street 22.doing nothing// I was actually - I was actually doing something// I was either going 23.to school or working/and at that time/I was working and going to school//

\section{Stanza 8: I Worked Until I Actually Found Another School}

24. and then I decided to, um, to stop going to school/and I just continued to

25.work/just work/work// until I actually found another school/and that was at the 26. The Opportunity Center//

The first two stanzas illustrate Jamahl's agency through his active searching for a way to return to formal education. The initial stanza emphasizes the actions that Jamahl was taking; he used the words "looking" or "look" eight times in this short stanza to impress upon his audience that he was serious about the search for a new educational program. He told his audience that he was not only looking online but also scanning the periodical from the city Housing Authority, the city department that manages the housing project where Jamahl and his family lived. This newspaper, read mainly by those living in the projects or receiving public assistance, "would actually bring up lists of schools, different schools, different GED, and stuff like that." Contrary to what Jamahl sees as the dominant perception of such a newspaper, the city Housing Authority periodical “actually" has lists of educational programs and schools in it. In the second stanza, Jamahl tells his audience about finding his second secondary-level educational program, exclaiming "I actually found one. I found Coolidge High School. That's actually right 
across the street from the high school that I went to." Again, contrary to what Jamahl perceives his junior year teacher and others may have expected of him, he was able to (re)position himself and find a better educational program. Throughout these stanzas, "actually" serves to build the significance of Jamahl's experience and contrast it with limiting expectations or framings.

In stanzas 3-6, Jamahl explained why that school, Coolidge, did not work out for him. In this second school, Jamahl "knew everyone there." He has difficulty explaining why this mattered to him in stanza three, but in the next stanza, he elaborates: "just being - the fact that I go to the school and a lot of kids that was from my old high school, they transferred over and went to that school. So I knew, I knew, I knew a lot of kids there." Jamahl had hoped that being in a new educational program would be different, but he feels that he and his peers were similarly positioned in this environment as well, and he was seeking a space where he will not be framed in these ways. In the next stanza, Jamahl asserted that he did not want his audience to draw the conclusion that he was uninterested in education because of his lack of interest in Coolidge. He was “feeling it, but...wasn't feeling it at the same time," meaning that he liked being in school but not this particular school. He asserted: "I was feeling the mood to go to school, but I just wasn't feeling the school and what was in the school, and it was making me lose interest." In stanza six, Jamahl explained that the school was not all that he had initially hoped. Beginning to describe the teachers, he shifts to "there was bookwork and stuff. I could do it, but it just wasn't something that I was looking for, seeking." Jamahl's experience of the school felt at odds with his stated goal of earning his diploma despite the fact that he knew that he was capable of achieving the academic tasks. 
Following these stanzas, in the final two stanzas (7-8), Jamahl resisted the notion that he was a passive person, someone uninterested in formal education. He was aware that his decision to leave two educational programs may have framed him in this way in some people's eyes, so he worked at the close of the narrative to further ward off this positioning. Further, he was aware that as a young man of color, there was a pejorative perception that he was more interested in "hanging out" in the street than pursuing his formal education or employment. In and through this narrative, Jamahl enacted the identity of a hard-working young man who values education and was willing to work hard to accomplish his goals, actively working to resist positioning stemming from dominant discourses about poor and working-class young men of color that suggest otherwise.

"Actually" served as this significance-building tool in these narratives. Jamahl used 'actually' three times as he warded off the perception that he did not care about education and that he was working instead of spending time "in the street doing nothing." It is this prevalent perception that Jamahl worked to challenge with his actual experience: the dominant discourse of young men of color as "nobodies". In these final two stanzas, he suggested that he felt negatively positioned as a low-wage worker as well (Jamahl shared elsewhere that these jobs were in restaurant food delivery and the fast food industry). Not only was he resisting being seen as a "drop-out", or someone uninterested in formal education, he resisted being framed as someone who will only work these sorts of jobs for the rest of his life.

\section{Actually becoming somebody}

Jamahl's (re)positionings allowed him to build an identity to counter the negative 
ways he had been framed, and through this identity Jamahl sought to engage a better, and more self-directed way of being-in-the-world. To highlight the utility of Jamahl (re)positioning himself in and through his narratives, particularly the agency afforded by these negotiations and emergent identity, I share one of Jamahl's narratives that I have entitled "Actually becoming somebody," which was shared in a focus group discussion with three other young men present. During this focus group session, he recounted the first time he recalled being negatively positioned in the space of school. It was about his first-grade teacher, a moment etched in his memory when she told him that he "wasn't gonna be nothin' in life." While a painful story for Jamahl, he returned to his elementary school years later, as a teenager, to both visit and challenge that teacher and her prophecy about him.

He recounted the narrative of this visit, focusing on what his experience had been when she told him that he would "be nothing." He again comes back to the notion that he had disproved this teacher's hurtful prophecy, recounting:

And at the time I was just thinking, I was like "damn, she just really told me that." And, not only from that, it was like, um, other situations in class, like I didn't like the teacher. 'Cause the way she would, um, the way she would handle things in class, and the - the things that she would say to other students too. So, that right there just led to that, like me not liking her. And-I showed her otherwise. Like, when she said to me that I was, wasn't gonna become nothin' in life. Showed her otherwise, and that was it.

Jamahl referenced the negative ways this teacher spoke to both him and other students. Jamahl jumped from this dislike for the teacher to "I showed her otherwise, like, when she said to me that I...wasn't gonna become nothin' in life." At this point, I wanted to know how Jamahl had "showed her otherwise," and I asked him to tell us what had happened when he went back to visit the school as a teenager. 
Jamahl then shared the following narrative emphasizing what was going on in his mind when he returned to the school. He began to tap his pen as he recounted that day.

\section{Table 2}

\section{Jamahl's story of Actually becoming somebody}

\section{Stanza 1: I had ownership of myself}

1.when I went back, I felt, I felt type, type-//

2.I felt like I had type ownership of myself, like-I/

3.I went there with the, with the-not the low standards that she left me with like you're 4. not gonna become nothin' in life

5.but I went there with the/ with the brains of like/ um//

6.look/ look at her// She's doing the same thing and you actually did something with your 7.life/l

\section{Stanza 2: In a position that I see myself in}

8.and you actually became something//

9.so that's how I looked at it/ at the time//

10.but-/it felt/ it felt type good just going there and seeing her/

11. and actually seeing me not in the position that she thought I would be in/ but in a 12.position that I see myself in//

When I asked Jamahl what position he sees himself in, he explained he is "putting myself out there, seeking help, just trying to do better for my life, and not become that nobody like she said I would become." Analysis of content, structural analysis, and a significance analysis focusing on the significance-building tool 'actually' all demonstrate Jamahl's agentive (re)positionings. Jamahl's narrative highlights his agency: he stated that he "felt like [he] had type ownership of himself," and that the teacher was "actually seeing [him] not in a position that she thought [he] would be in, but in a position [he] see[s] himself in." Unlike the preface to this narrative, which focuses on the negative ways he was positioned by this teacher as a first-grade child, the narrative focused on his actual experience that challenged those negative framings of who he was or could become.

"Actually" is used three times here. Looking at the narrative in relation to its preface, the 
narrative counters the negative experiences depicted a few moments earlier; Jamahl exclaimed "you actually did something with your life, you actually became something."

In addition to the significance-building tool 'actually', the analytic focus on deictics also demonstrated Jamahl's agency. What is of particular interest in this narrative is whom Jamahl imagines himself talking to when he spoke about himself. The "you" that Jamahl was speaking of was himself, and the context told his audience that he was shifting from the first person to the teacher's subjective vantage point. In resisting the negative positioning of the first grade teacher, he moved from "I felt" and "I went there" to imagine himself occupying her subjectivity with 'you're not gonna become nothin' in life." He was able to (re)position himself within her subjectivity: the hurtful prophecy becomes "you actually did something with your life." He made his experience into a narrative of overcoming, seeing himself through her eyes and imagining the shift. Not only was he in a position that he saw himself in — he (re)positioned himself — but he was entering her subjectivity and looking at himself as he imagined she saw him: a young man, in school, working hard to graduate and explore the world. Jamahl's imagined "actual" viewing of himself through the teacher's eyes challenged the longstanding effects of her judgment that he would not become anything in life. In this instance, Jamahl internalized both his own "actual" self-image and the negative image of himself that he imagined his former teacher had since he was in the first grade. Further, he exercised his agency as he pushed back against the negative image of himself and replaced it with a counter-story, a positive articulation of his identity.

\section{Discussion}

\section{The dialogical process of culturally-responsive pedagogies}


Clearly, the individual teacher who told young Jamahl that he "wasn't gonna be nothin"” had extremely low expectations of him, positioning him as a walking deficit. While it is not my intention here to disparage educators, or to draw on the cultural myths that suggest that teachers are saviors who can somehow transcend all inequities that exist in current educational and other social systems, this sort of positioning is inexcusable and contributes to the framings with which people like Jamahl must contend. The importance of high expectations and the generative positioning of students has been well-documented (e.g., Allen \& White-Smith, 2014; Diamond, Randolph, \& Spillane, 2004; Tenenbaum \& Ruck, 2007), yet the ways in which marginalized learners negotiate pejorative discourses and the cultural tools they draw upon has received less attention in the literature.

Engaging the conceptual frame double-consciousness and the tradition of counterstorytelling, Jamahl's narratives can be read as situated actions indexical to his identity negotiations, specifically a means of (re)positioning himself in relation to educational disparity discourse. The knowledge built through this systematic analysis suggests that such situated actions and associated meanings are of great importance to pedagogies that seek to be culturally-responsive. Drawing on his actual experience served as a resource as Jamahl exercised his agency to counter the pejorative discourses with which he is forced to contend as he seeks to advance in and through formal education. Jamahl is both being pushed into acceptance of a particular framing of who he is and resisting this positioning, an ongoing negotiation that Jamahl asserted exists both within and beyond school when participating in the member checking process.

It is only through an understanding of the undesirable discourses that he is resisting and an awareness of the cultural tools he employs in his resistance that a 
pedagogy might aim to be responsive to his desires and needs. Culture, understood here as the tools and resources, including literacies, that people draw on as they work to position themselves in social space, should not be assumed to be stable or static, but continuously requiring researchers and practitioners to be "sociologists of the local" (Luke, 1995). This requires learning about individuals' ways of meaning-making, specific strategies related to the navigation of dominant discourses, and local lived realities as part of the dialogical process of a culturally-responsive pedagogy. During the individual interviews and member checking process, Jamahl recognized these resources as his identity as a self-taught photographer, his numerous work experiences, and the ways his dedication to earning his diploma lead him to seek out new educational programs. If Jamahl's teachers had both the structural working conditions and the desire to know Jamahl beyond the entrenched deficiency discourses about African American men that exist in schooling and other social systems, these resources could inform responsive and meaningful teaching/learning practices.

\section{Grounding culturally-responsive pedagogies}

I began this research with the desire to know more about the ways that Jamahl understood how he was positioned within educational disparity discourse and how he worked to resist these framings. These identity negotiations are a contrast with the understanding of people like Jamahl as "at-risk," suggesting people acted upon but possessing little capability themselves to act. Jamahl's successful (re)positioning of himself as a seeker of formal education, as someone other than a person who isn't "gonna become nothin' in life" says much about education and agency. Deficiency discourses framing African American young men like Jamahl circulate throughout educational 
research and reform as well as the wider society, engendering continual re-positioning efforts on the part of as minoritized people as they seek to mitigate the effects of these positionings (Allen, 2017; Harper \& Davis III, 2012).

This narrative analysis case study speaks to tensions regarding agency and sociocultural determination, and the ways positioning in micro-level spaces can serve to reinforce or interrupt broader discursive positionings. Analysis of Jamahl's narratives demonstrated his taking up subject positions in agentive ways. Resisting the subject positions he is offered within the worlds of formal education, he drew on his own understandings of his experience to position himself as a "somebody". These (re)positionings could serve as generative starting points in the teaching/learning process; and they stand in contrast to the de facto assumption of Jamahl at the early morning meeting of his teachers in which he was positioned as a complilation of literacy skill deficits.

In detailing Jamahl's drawing on the resource of his double-consciousness to resist the negative interpellations, I do not intend to invoke meritocratic narratives of overcoming the odds, or Horatio Alger mythologies. There remain broader forces at work that can limit marginalized students; (re)positional identities in classroom spaces, even when educators attempt to position themselves as allies (Ives, 2012). In exploring Jamahl's narratives, and analyzing his work to (re)position himself as a learner and active seeker of education rather than the 'nothing' he was positioned as, renegotiated identities should not be viewed as a panacea. Simplistic discussions of agency can easily slide into the "bootstraps" mythology that pervades much of our national political discourse. It is also worth noting that agency can be reproductive as well as transformational (Bourdieu, 
2011; Willis, 1977), and that further empirical work is needed to understand why and in which contexts particular resources or supports bolster transformational agency and negotiated identity work. Agency, here, must thus be understood as the negotiation of social structures and practices, not the absence or overcoming of them (Fairclough, 2003). Engaging (re)positioning practices within research and educational practitioner communities can identify meaningful sites of resistance to negative dominant discourses stemming from limiting social structures and practices.

This narrative analysis case study contributes to understandings of how individuals mobilize and employ tools and resources as they agentively work to (re)position themselves. To work towards conditions that engender justice in and through schooling, researchers must continue to investigate the ways minoritized youth like Jamahl draw on cultural resources to resist and renegotiate their positions in social spaces. This study has ramifications for educational practice: it serves as a reminder that “students' positions...need not be equated with their dispositions" (Luttrell \& Parker, 2001, p.245). While acknowledging the ways a person is positioned can have substantial effects on self-understandings, behaviors, and courses of action, culturally-responsive and sustaining pedagogies can work to mitigate limiting discursive effects when situated in dialogical and responsive practices. 


\section{References}

Allen, Q., \& White-Smith, K. A. (2014). "Just as Bad as Prisons": The Challenge of Dismantling the School-to-Prison Pipeline Through Teacher and Community Education. Equity \& Excellence in Education, 47, 445-460.

Allen, Q. (2017). "They write me off and don't give me a chance to learn anything": Positioning, discipline, and Black masculinities in school. Anthropology \& Education Quarterly, 48, 269-283.

Atwood, E., \& López, G. R. (2014). Let's be critically honest: towards a messier counterstory in critical race theory. International Journal of Qualitative Studies in Education, 27, 1134-1154.

Bal, A., \& Trainor, A. A. (2016). Culturally Responsive Experimental Intervention Studies The Development of a Rubric for Paradigm Expansion. Review of Educational Research, 82, 319-359.

Bamberg, M. (2004a). Considering counter-narratives. In Bamberg, M. \& Andrews, M. (Ed.s) Considering Counter-Narratives: Narrating, Resisting, Making Sense (351371). Philadelphia, PA: John Benjamins.

Bamberg, M. (2004b). Positioning with Davie Hogan. In Daiute, C. \& Lightfoot,C. (Eds.) Narrative analysis: Studying the development of individuals in society (135-158). Thousand Oaks, CA: Sage.

Borrero, N. E., Flores, E., \& de la Cruz, G. (2016). Developing and Enacting Culturally Relevant Pedagogy: Voices of New Teachers of Color. Equity \& Excellence in Education, 49, 27-40.

Bourdieu, P. (1977). Outline of a theory of practice. Cambridge, UK: Cambridge University Press.

Bourdieu, P. (2011). The forms of capital. (1986). Cultural theory: An anthology, 81-93.

Butler, T. (2017). "We need a song": Sustaining critical youth organizing literacies through world humanities. Equity \& Excellence in Education, 50, 84-95.

Campano, G., Ghiso, M., \& Sánchez, L. (2013). "Nobody knows the...amount of a person": elementary students critiquing dehumanization through organic critical literacies. Research in the Teaching of English, 48, 98-125.

Carrillo, J. F. (2016). I Grew Up Straight 'hood: Unpacking the Intelligences of WorkingClass Latino Male College Students in North Carolina. Equity \& Excellence in Education, 49, 157-169. 
Chandler, M., Lalonde, C., \& Teucher, U. (2004). Culture, continuity, and the limits of narrativity. In Daiute, C. \& Lightfoot,C. (Eds.) Narrative analysis: Studying the development of individuals in society (245-266). Thousand Oaks, CA: Sage.

Cho, H. (2016). Racism and linguicism: engaging language minority pre-service teachers in counter-storytelling. Race Ethnicity and Education, 5, 1-15.

Connor, D. J. (2006). Michael's Story: "I get into so much trouble just by walking": Narrative Knowing and Life at the Intersections of Learning Disability, Race, and Class. Equity \& Excellence in Education, 39, 154-165.

Daiute, C. (2014). Narrative inquiry: A dynamic approach. Thousand Oaks, CA: Sage.

Davies, B., \& Harré, R. (1990). Positioning: the discursive production of selves. Journal for the Theory of Social Behaviour, 20, 43-63.

Delgado, R., \& Stefancic, J. (2012). Critical race theory: An introduction. New York, NY: NYU Press.

Diamond, J. B., Randolph, A., \& Spillane, J. P. (2004). Teachers' expectations and sense of responsibility for student learning: The importance of race, class, and organizational habitus. Anthropology \& Education Quarterly, 35, 75-98.

Du Bois, W.E.B. (2008). The souls of black folk. New York, NY: Oxford University Press.

Erstad, O., Gilje, Ø., Sefton-Green, J., \& Vasbø, K. (2009). Exploring 'learning lives’: community, identity, literacy and meaning. Literacy, 43, 100-106.

Fairbanks, C. M. \& Ariail, M. (2006). The role of social and cultural resources in literacy and schooling: Three contrasting cases. Research in the Teaching of English, 40, 310-354.

Fairclough, N. (2003). Analysing discourse: Textual analysis for social research. New York, NY: Routledge.

Fernández, E. (2016). Illuminating Agency: A Latin@ Immigrant Parent's Testimonio on the Intersection of Immigration Reform and Schools. Equity \& Excellence in Education, 49, 350-362.

Gee, J.P. (1991). A linguistic approach to narrative. Journal of Narrative and Life History/Narrative inquiry, 1, 15-39.

Gee, J.P. (2001). Identity as an analytic lens for research in education. Review of Research in Education, 25, 99-25. 
Gee, J.P. (2011). How to do Discourse Analysis: A Toolkit. New York, New York: Routledge.

Golden, N.A. (2015). There's Still That Window That's Open": The Problem With 'Grit'. Urban Education, 52, 343-369.

González, N., Moll, L., and Amanti, C. (2005). Funds of Knowledge: Theorizing Practices in Households, Communities, and Classrooms. Mahwah: Lawrence Erlbaum Associates.

Gorski, P. (2012). Perceiving the problem of poverty and schooling: Deconstructing the class stereotypes that misshape education policy and practice. Equity \& Excellence in Education, 45, 302-319.

Hall, L. A. (2012). The role of reading identities and reading abilities in students' discussions about texts and comprehension strategies. Journal of Literacy Research, 44, 239-272.

Harper, S. R., \& Davis III, C. H. (2012). They (don't) care about education: A counternarrative on Black male students' responses to inequitable schooling. The Journal of Educational Foundations, 26, 103-121.

Harrington, M. (1962). The other America: Poverty in the United States. New York, NY: Macmillan.

Harré, R. and van Langenhove, L. (1999). Varieties of Positioning. Journal for the Theory of Social Behavior, 21, 393-407.

Harré, R., Moghaddam, F., Cairnie, P., Rothbart, D., \& Sabat, S. (2009). Recent advances in positioning theory. Theory and Psychology, 19, 5-31.

Holland, D. and Leander, K. (2004). Ethnographic studies of positioning and subjectivity: an introduction. Ethos, 32, 127-139.

Hull, G. \& Katz, M.L. (2006). Crafting an agentive self: case studies of digital storytelling. Research in the Teaching of English, 41, 43-81.

Hull, G. A., \& Zacher, J. (2007). Enacting identities: An ethnography of a job training program. Identity: An International Journal of Theory and Research, 7, 71-102.

Irizarry, J. (2017). "For us, by us": A vision for culturally-sustaining pedagogies forwarded by Latinx youth. In Paris, D. \& Alim, H.S. (Eds.) Culturally Sustaining Pedagogies: Teaching for Learning and Justice in a Changing World (83-98). New York: Teachers College Press. 
Ives, D. (2012). Kristina's" Ghetto Family": Tensions and Possibilities at the Intersection of Teacher and Student Literacy Agendas. Research in the Teaching of English, 47, 39-63.

Kirkland, D. E. (2009). The skin we ink: Tattoos, literacy, and a new English education. English Education, 41, 375-395.

Kirkland, D. E. (2013). A search past silence: The literacy of young Black men. New York, NY: Teachers College Press.

Ladson-Billings, G. (1995). Toward a Theory of Culturally-relevant Pedagogy. American Educational Research Journal, 32, 465-491.

Ladson-Billings, G. (2006). It's not the culture of poverty, it's the poverty of culture: the problem with teacher education. Anthropology and Education Quarterly, 37, 1 104-109.

Ladson-Billings, G. (2014). Culturally relevant pedagogy 2.0: aka the remix. Harvard Educational Review, 84, 74-84.

Leander, K. (2002). Locating Latanya: the situated production of identity artifacts in classroom identification. Research in the Teaching of English, 37, 198-250.

Lewis, C. \& Moje, C. (2007). Examining opportunities to learn literacy: the role of critical sociocultural research. In Lewis, C., Enciso, P., \& Moje, E. (Eds.) Reframing sociocultural research on literacy: identity, agency, and power. New York, NY: Routledge.

Lincoln, Y.S. \& Guba, E.G. (1985). Naturalistic inquiry. Beverly Hills, CA: Sage.

Luke, A. (1995). When Literacy Might (Not) Make a Difference: Textual Practice and Capital. Paper presented at the American Educational Research Association Annual Conference, April.

Luttrell, W. and Parker, C. (2001). High school students' literacy practices and identities, and the figured world of school. Journal of Research in Reading, 24, 235-247.

Maynes, M., Pierce, J., \& Laslett, B. (2008). Telling Stories: The Use of Personal Narratives in the Social Sciences and History. Ithaca, NY: Cornell University Press.

Mazzei, L. \& Jackson, A. (2012). Complicating voice in a refusal to "Let participants speak for themselves. Qualitative Inquiry, 18, 745-751.

Milner IV, H. R. (2011). Culturally relevant pedagogy in a diverse urban classroom. The Urban Review, 43, 66-89. 
Noguera, P. (2009). The trouble with black boys:... And other reflections on race, equity, and the future of public education. Hoboken, NJ: John Wiley \& Sons.

Paris, D. (2012). Culturally Sustaining Pedagogy: A Needed Change in Stance, Terminology, and Practice. Educational Researcher, 41, 93-97.

Paris, D.,\& Alim, H. S. (2014). What are we seeking to sustain through culturally sustaining pedagogy? A loving critique forward. Harvard Educational Review, 84, 85-100.

Paris, D., \& Alim, H. S. (Eds.). (2017). Culturally sustaining pedagogies: Teaching and learning for justice in a changing world. Teachers College Press.

Payne, Y. A., \& Brown, T. M. (2010). The educational experiences of street-life-oriented black boys: How black boys use street life as a site of resilience in high school. Journal of Contemporary Criminal Justice, 26, 316-338.

Purcell-Gates, V. (2013). Literacy Worlds of Children of Migrant Farmworker Communities Participating in a Migrant Head Start Program. Research in the Teaching of English, 48, 68-97.

Riessman, C. (1993). Narrative Analysis. Newbury Park, California: Sage Publications.

Riessman, C. (2008). Narrative Methods for the Human Sciences. Los Angeles, California: Sage Publications.

Rosa, J. \& Flores, N. (2017). Do you hear what I hear? Raciolinguistic ideologies and culturally-sustaining pedagogies. In Paris, D. \& Alim, H.S. (Eds.) Culturally Sustaining Pedagogies: Teaching for Learning and Justice in a Changing World (175-190). New York: Teachers College Press.

Rosario-Ramos, E. \& Johnson, L. (2014). Communities as counter-storytelling (con)texts: the role of community-based educational institutions in the development of critical literacy and transformative action. In Pandya, J. \& Ávila, J. (Eds.) Moving Critical Literacies Forward (113-126). New York: Routledge.

San Pedro, T. J. (2015). Silence as shields: Agency and resistances among Native American students in the urban Southwest. Research in the Teaching of English, 50, 132-153.

San Pedro, T.J. (2017). "This stuff interests me": Re-centering indigenous paradigms in colonizing schooling spaces. In Paris, D. \& Alim, H.S. (Eds.) Culturally Sustaining Pedagogies: Teaching for Learning and Justice in a Changing World (99-116). New York: Teachers College Press. 
Sealey-Ruiz, Y. (2011). The use of educational documentary in urban teacher education: A case study of beyond the bricks. The Journal of Negro Education, 80, 310-324.

Sealey-Ruiz, Y. (2013). Learning to resist: educational counter-narratives of Black college re-entry mothers. Teachers College Record, 115, 1-31.

Sleeter, C. E. (2012). Confronting the marginalization of culturally responsive pedagogy. Urban Education, 47, 562-584.

Solorzano, D. G., \& Yosso, T. J. (2001). Critical race and LatCrit theory and method: Counter-storytelling. International Journal of Qualitative Studies in Education, 14, 471-495.

Solorzano, D. G., \& Yosso, T. J. (2010). Counterspaces in a hostile place. In Patton, L. (Ed.), Culture centers in higher education: Perspectives on identity, theory, and practice, 83-104. Sterling, VA: Stylus.

Tenenbaum, H. R., \& Ruck, M. D. (2007). Are teachers' expectations different for racial minority than for European American students? A meta-analysis. Journal of educational psychology, 99, 253-273.

Toolan, M. (1988). Narrative: A Critical Linguistic Introduction. New York, New York: Routledge.

Tuck, E. (2009). Suspending damage: A letter to communities. Harvard Educational Review, 79, 409-428.

Willis, P. E. (1977). Learning to labor: How working class kids get working class jobs. Columbia University Press.

Winn, M. T. (2012). The politics of desire and possibility in urban playwriting:(re) reading and (re) writing the script. Pedagogies: An International Journal, 7, 317332.

Wortham, S. (2004). From Good Student to Outcast: The Emergence of a Classroom Identity. Ethos, 32, 164-187. 